Research, part of a Special Feature on Integrating Indigenous Ecological Knowledge and Science in Natural Resource Management: Perspectives from Australia

\title{
A Typology of Indigenous Engagement in Australian Environmental Management: Implications for Knowledge Integration and Social- ecological System Sustainability
}

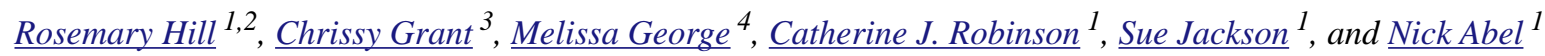

\begin{abstract}
Indigenous peoples now engage with many decentralized approaches to environmental management that offer opportunities for integration of Indigenous Ecological Knowledge (IEK) and western science to promote cultural diversity in the management of social-ecological system sustainability. Nevertheless, processes of combining IEK with western science are diverse and affected by numerous factors, including the adaptive co-management context, the intrinsic characteristics of the natural resources, and the governance systems. We present a typology of Indigenous engagement in environmental management, derived through comparative analysis of 21 Australian case studies, and consider its implications for the integration of IEK with western science. Sociological and rational choice institutionalism underpin our analytical framework, which differentiates on three axes: (1) power sharing, incorporating decision making, rules definition, resource values and property rights; (2) participation, incorporating participatory processes, organizations engaged, and coordination approaches; (3) intercultural purpose, incorporating purposes of environmental management, Indigenous engagement, Indigenous development and capacity building. Our typology groups engagement into four types: Indigenous governed collaborations; Indigenous-driven cogovernance; agency-driven co-governance; and agency governance. From our analysis of manifestations of knowledge integration across the types, we argue that Indigenous governance and Indigenous-driven co-governance provides better prospects for integration of IEK and western science for sustainability of social-ecological systems. Supporting Indigenous governance without, or with only a limited requirement for power sharing with other agencies sustains the distinct Indigenous cultural purposes underpinning IEK, and benefits knowledge integration. We conclude by advocating that the typology be applied to test its general effectiveness in guiding practitioners and researchers to develop robust governance for Indigenous knowledge integration in environmental management.
\end{abstract}

Key Words: environmental planning; Indigenous ecological knowledge; integration; intercultural; governance; natural resource management

\section{INTRODUCTION}

Indigenous peoples' engagement in environmental management is increasing globally as a result of recognition of their rights, interests, and the worth of their Indigenous Ecological Knowledge (IEK) (Hill et al. 1999, Houde 2007, Nakanura 2008). Recent developments in considering environmental management as an aspect of complex social-ecological system dynamics has identified that integration of IEK with western science can enhance system attributes associated with sustainability (Berkes 2004, Folke 2004, Walker and Salt 2006, Carpenter et al. 2009, Chapin III et al. 2010). We recognize that sustainability has many dimensions and meanings, and adopt here Dawson et al.'s (2010:2845) definition that "a sustainable SES is one that, over the normal cycle of pressures and disturbance events, maintains its characteristic diversity of major functional groups, processes, services and utility thereby ensuring its capacity to endure". Bohensky and Maru's (2011) review of a decade of international literature on the integration of Indigenous knowledge and science concluded that there remains a lack of clarity and empirical evidence that can help distinguish how indigenous knowledge and knowledge integration contribute most to resilience. Resilience is recognized alongside adaptability and transformability as a key determinant of system dynamics and sustainability (Walker et al. 2006, Gooch and Warburton 2009).

In Australia, Indigenous peoples engage in environmental management with multiple stakeholders (governments, scientists, producer groups, conservationists, and others) through a range of mechanisms: natural resource management (Roughley and Williams 2007); native title agreements (Hill 2006, Agius et al. 2007); Indigenous and co-managed protected areas (Muller 2003, Nursey-Bray and Rist 2009, Ross et al. 2009); endangered species initiatives (Nursey-Bray 2009); water planning processes (Jackson 2009, Jackson and Altman 2009); and in the pursuit of cultural objectives conventionally in the absence of non-Indigenous actors (La Fontaine 2006). Understanding approaches to knowledge integration in these diverse Australian examples may help build global understanding of the processes of IEK and western science integration to manage for sustainability. However, 
integration is affected by diverse factors including approaches to inquiry into IEK, adaptive co-management context, and the intrinsic qualities of the natural resource (Agrawal 2002, Davies 2003, Telfer and Garde 2006, Davies and Holcombe 2009, Wohling 2009, Davis and Ruddle 2010). Governance forms, including power relationships, multi-scalar polycentric connections, orchestration of networks, and negotiation of diverse Indigenous and state institutions, shape interactions that block, bridge or enable integration of IEK and western science (Olsson et al. 2004, Folke et al. 2005, Olsson et al. 2006, Ostrom 2007).

Australian Indigenous peoples assert sovereign rights and interests to collective self-determination and control over their customary estates, despite profound impacts from the colonial processes of territorial acquisition and state formation. The policy mechanisms established by Australian governments to respond to Indigenous claims have resulted in Indigenous control and responsibility for the environmental management of about one-fifth of the continental land mass, much of which is of high conservation significance (Hibbard and Lane 2004, Altman et al. 2007, Lane and Williams 2009). However, Indigenous peoples suffer capacity constraints in meeting their environmental management needs for these lands (Aboriginal \& Torres Strait Islander Social Justice Commissioner 2009). The socioeconomic disadvantage faced by Indigenous peoples is a key constraint, reflected in the life expectancy gap with non-Indigenous people of twelve years (Australian Institute of Health and Welfare 2010). Projects that seek to engage Indigenous peoples in environmental management always encounter the politics of Indigenous rights and the context of Indigenous socioeconomic disadvantage as key determinants of success (Palmer 2006, Davidson and O'Flaherty 2007). These distinctive features suggest that characteristics of Indigenous peoples' engagement will differ significantly from the general characteristics of "public" engagement in environmental management.

Typologies are useful for interrogating characteristics and building practice and theory in environmental management; for example, a recent typology of collaboration provides guidance for conveners on designing types of collaboration for solving particular types of problems, and for theoreticians on choosing between frameworks (Margerum 2008). Many existing typologies differentiate on the basis of a power sharing continuum of participation from passive information dissemination to citizen empowerment (Arnstein 1969, Head 2007, Reed 2008). Others differentiate on the basis of purposes, for example between pragmatic versus normative participation, between diagnostic versus co-learning, and between planning-centered and people-centered (Michener 1998, Lynam et al. 2007, Reed 2008). Reed (2008) found that these typologies assist in unpacking the loaded ideological interpretations and diverse methodologies for participation, thereby providing assistance in choosing a participatory method. Nevertheless, existing typologies do not address the issue of Indigenous rights, and the context of Indigenous socioeconomic disadvantage as previously noted. There is currently no typology of Indigenous engagement in environmental management in Australia, despite the proliferation of engagement mechanisms and examples, and the recognized relevance of IEK and western science integration for sustainability (Natural Resource Management Ministerial Council 2010).

Our research goal was to develop a typology that would be useful in interrogating the characteristics of Indigenous engagement in Australian environmental management, analyze approaches to integration of IEK and western science that occurred organically as part of the engagement, and consider implications for management of sustainability in social-ecological systems (SES). We first present the theoretical foundations and definitions of governance, Indigenous governance, and IEK from which we conduct our research, followed by the methods for case study selection and analysis. A description of the typology, the four types, and differences between them follows. We subsequently present our analysis of the influence of governance type on integration of IEK and science. Our conclusion considers implications of the typology for theory and practice of Indigenous engagement and knowledge integration for sustainability in SES.

\section{Theoretical foundations and definitions}

Governance is defined as the structures and processes by which people in societies make decisions and share power (Folke et al. 2005, Lebel et al. 2006, Winter 2006, Ostrom 2007). Environmental governance, the making of societal decisions about the environment, is currently developing new multilevel, polycentric forms, partly through governmentdesigned decentralization, and also by community-led development of new multilevel institutions in response to global changes (Dietz et al. 2003, Selin and VanDeveer 2009, Cundill and Fabricius 2010, Hill et al. 2010). In Australia, this global trend has manifested in significant rescaling of environmental governance, mixing "top- down" directives from government with "bottom-up" approaches in which citizens participate directly in policy formulation and implementation (Lane et al. 2009). These new forms of governance display significant attention to mechanisms for integrating multiple knowledge systems, including IEK, to manage for sustainability (Folke et al. 2005, Ballard et al. 2008).

In considering the features of Indigenous knowledge and governance systems, we adopt Martinez-Cobo's (1986) working definition of Indigenous peoples as those who, having a historical continuity with precolonial societies that developed on their territories, consider themselves distinct from other sectors of the societies now prevailing on parts or all of those territories. These distinct Indigenous societies are 
recognized as the holders of IEK, defined as a cumulative body of knowledge, practice, and belief evolving by adaptive processes and handed down through generations by cultural transmission (Berkes 2004). IEK forms part of governance and cultural systems that encompass language, naming, and classification systems, resource use practices, rituals, spirituality, and worldviews (International Council for Science 2002). In Australia, Indigenous peoples maintain distinct forms of governance despite their location in a postcolonial frame in which the nation-state has overarching sovereign power (Smith and Hunt 2008). Distinctive features include an emphasis on networks, nodal modes of leadership within these networks, and dispersed distribution of powers among self-defined social groups. Australian Indigenous governance systems connect IEK with cultural rights:

Knowledge has a powerful dialectic element: it points to country and to relationships between the possessor of knowledge and the country to which it refers. Performance of knowledge (through song, dance, story, history, use of country) is a performance of ownership: it identifies the person as one with rights and responsibilities to that country (Rose 1994:2).

Recognition that diversity in Indigenous governance influences how IEK is integrated into environmental management stimulated our interest in developing a typology (Ross and Pickering 2002, Fernandez-Gimenez et al. 2006, Sveiby 2009). Multiple frameworks related to governance were identified as potentially relevant, including multilevel, effective, adaptive, and collaborative governance, drawing attention to diverse attributes including legitimacy, accountability, cross-scale connectivity, problem-solving arenas, and leadership (Folke et al. 2005, Head 2009, Lockwood et al. 2009, Lockwood 2010). We synthesized these multiple analytical frameworks of governance in comanagement through recognizing their roots in: (1) rational choice institutionalism, drawing on the assumption in neoclassical economics that actors behave as utility maximizers to rank their priorities within institutional constraints; and (2) sociological institutionalism, drawing on constructivism and the assumption that political and cultural environments alter actors' views of utility (Sandström 2009). Rational choice institutionalism directs attention to structures, including property rights, other rules and rule-making, while sociological institutionalism emphasizes functions, including problem-solving processes, capacity building, and relationships (Plummer and FitzGibbon 2004, Carlsson and Berkes 2005, Ostrom 2007, 2008, Ostrom and Cox 2010, Hill 2011). Three key concepts are common to both frameworks: power-sharing, participation, and process (Plummer and FitzGibbon 2004, Sandström 2009). We utilized these three concepts in our analysis, focusing the "process" dimension onto intercultural purposes, in recognition of the context of Indigenous rights,
Indigenous socioeconomic disadvantage, and the distinctive features of Indigenous governance (Porter 2004, Natcher et al. 2005, Palmer 2006, Hunt et al. 2008). Our use of the term "intercultural" draws on recognition of the relational dimensions of social forms that develop through the interaction of Indigenous and non-Indigenous societies, providing opportunities for innovation (Hinkson and Smith 2005, Merlan 2005, Bakker and Bridge 2006, Suchet-Pearson and Howitt 2006).

\section{METHODS}

\section{Case study selection and analysis}

The typology is based on pattern identification through comparative analysis of 21 Australian case studies in environmental management (Table 1). The case studies were selected using a variation sampling method, aiming to provide geographical spread (Figure 1) and encapsulate a diversity of settings including within protected areas, natural resource management and research projects, terrestrial and marine settings, and both government and nongovernment initiatives (Liamputtong and Ezzy 2005). Our selection of case studies was not specifically influenced by the approaches to knowledge integration that they used and none of the case studies had knowledge integration as their primary goal. The availability of data also affected choice of case studies. Table 1 lists the key organizations and instruments underpinning the Indigenous engagement, including an array of agreements, legislation, regulations, plans, frameworks, and oral tradition. Forms of IEK involved in each case study are also listed.

Data for the analysis of the case studies included formal published plans, reports, journal articles, web pages, newspaper articles, and a range of informal internal reports, memoranda, and meeting minutes. At least one author had direct interaction with each of the case studies either as a scholar or practitioner, and contributed participant observation data and/or empirical insight.

The data were used to classify each case study according to the three dimensions of the analytical framework, each with several categories:

1. power-sharing, incorporating decision making level and control, rules definition, resource cultural values and property rights;

2. participation, incorporating participatory processes and functions, organizations engaged, and coordination;

3. intercultural purpose, incorporating purposes of environmental management project or program; of Indigenous engagement; of Indigenous development, and of capacity building.

The method of classification was iterative, involving qualitative techniques of conceptual cluster analysis and 
Table 1. The case studies

\begin{tabular}{|c|c|c|c|}
\hline Case study & Key organizations & Key instruments for the Indigenous engagement & Forms of IEK \\
\hline \multicolumn{4}{|c|}{ Indigenous-governed collaborations IG } \\
\hline Murray and Lower & Indigenous Nations of the & Constitution of the Murray Lower Darling River & Indigenous use and occupancy \\
\hline $\begin{array}{l}\text { Darling Rivers Indigenous } \\
\text { Nations (MLDRIN) }\end{array}$ & Murray and Lower Darling & Indigenous Nations & $\begin{array}{l}\text { mapping, cultural heritage sites } \\
\text { assessments }\end{array}$ \\
\hline $\begin{array}{l}\text { Northern Australia Land } \\
\text { and Sea Management } \\
\text { Alliance (NAILSMA) }\end{array}$ & NAILSMA Board & $\begin{array}{l}\text { Heads of Agreement between Kimberley Land Council, } \\
\text { Northern Land Council and Balkanu }\end{array}$ & $\begin{array}{l}\text { On-country digital video } \\
\text { recording, language posters of } \\
\text { ethnobotany and zoology }\end{array}$ \\
\hline \multicolumn{4}{|c|}{ Indigenous-driven co-governance ICoG } \\
\hline $\begin{array}{l}\text { Cape York Caring for } \\
\text { Country }\end{array}$ & $\begin{array}{l}\text { Balkanu Cape York } \\
\text { Development Corporation }\end{array}$ & $\begin{array}{l}\text { Cape York Agenda of the Cape York Institute and } \\
\text { partners }\end{array}$ & $\begin{array}{l}\text { On-country digital video } \\
\text { recording, digital databases }\end{array}$ \\
\hline Dhimurru IPA, Sea & Dhimurru Land Management & Indigenous Protected Areas within the National Reserve & Art, language, story, on-country \\
\hline Country Plan & Aboriginal Corporation & System & knowledge transmission \\
\hline $\begin{array}{l}\text { Djabugay Indigenous } \\
\text { Land Management } \\
\text { Techniques }\end{array}$ & $\begin{array}{l}\text { Djabugay Tribal Aboriginal } \\
\text { Corporation }\end{array}$ & Indigenous customary law/lore & $\begin{array}{l}\text { Photographic recording, on- } \\
\text { country knowledge transmission }\end{array}$ \\
\hline Djelk Rangers & $\begin{array}{l}\text { Bawinanga Aboriginal } \\
\text { Corporation }\end{array}$ & $\begin{array}{l}\text { Northern Land Council Rangers Program; also now an } \\
\text { IPA }\end{array}$ & $\begin{array}{l}\text { Indigenous fire management, art, } \\
\text { language }\end{array}$ \\
\hline Kimberley Appropriate & KLC, ACF, EK Steering & Kimberley Land Council, Australian Conservation & Art, language, photographic \\
\hline Economies Roundtable & Committee & $\begin{array}{l}\text { Foundation and Environs Kimberley Letter of Agreement } \\
2004\end{array}$ & recording \\
\hline Lake Condah Sustainable & Winda Mara Aboriginal & Aboriginal Land (Lake Condah and Framlingham Forest) & Cultural and archaeological site \\
\hline Development Project & Corporation & Act 1987 (Cth) & recording \\
\hline Miriuwung-Gajerrong & MG Corporation & Ord Final Agreement; MG native title determinations & Art, language, on-country \\
\hline Cultural Planning & & & knowledge transmission \\
\hline Ngarrindjeri Nation Sea & Ngarrindjeri Regional & South-east Regional Marine Plan; Regional Partnership & Indigenous use and occupancy \\
\hline Country Plan & Authority & Agreement & mapping \\
\hline Victorian Native Title & Victorian Traditional Owner & Indigenous Management Agreements under the & Indigenous knowledge of rights \\
\hline Settlement Framework & Land Justice Group & Framework & over country \\
\hline \multicolumn{4}{|c|}{ Agency-driven co-governance ACoG } \\
\hline Cape York Peninsula & CYP Tenure Resolution & Cape York Land Use Heads of Agreement; Cape York & On-country knowledge \\
\hline Tenure Resolution & Implementation Group & Peninsula Heritage Act 2007 (Qld) & transmission, site documentation \\
\hline $\begin{array}{l}\text { Desert Livelihoods } \\
\text { Inland }^{\mathrm{TM}}\end{array}$ & $\begin{array}{l}\text { Desert Knowledge } \\
\text { Cooperative Research Centre }\end{array}$ & $\begin{array}{l}\text { Sustainable Livelihoods Framework, research agreements } \\
\text { between partners }\end{array}$ & $\begin{array}{l}\text { On-country transmission, co- } \\
\text { research, scientists and Indigenous } \\
\text { peoples }\end{array}$ \\
\hline $\begin{array}{l}\text { Eastern Kuku-Yalanji } \\
\text { ILUA }\end{array}$ & $\begin{array}{l}\text { Jabalbina Aboriginal } \\
\text { Corporation }\end{array}$ & Native Title Acts & $\begin{array}{l}\text { On-country transmission, photos/ } \\
\text { documents }\end{array}$ \\
\hline Healthy Country, Healthy & Joint Australian and Northern & Schedule 2.5 to the Overarching Agreement on & Rangers, on-country transmission, \\
\hline People & $\begin{array}{l}\text { Territory Government Steering } \\
\text { Committee }\end{array}$ & Indigenous Affairs & photo/documents \\
\hline Mutawintji National Park & $\begin{array}{l}\text { Mutawintji Board of } \\
\text { Management }\end{array}$ & Mutawintji National Park Lease (agreement) & $\begin{array}{l}\text { On-country transmission, cultural } \\
\text { heritage site recording }\end{array}$ \\
\hline Urannah Station & $\begin{array}{l}\text { Indigenous Land Corporation; } \\
\text { Urannah Property Association }\end{array}$ & Aboriginal and Torres Strait Islander Act 2005 & On-country transmission \\
\hline $\begin{array}{l}\text { Wet Tropics Regional } \\
\text { Agreement } \\
\text { Agency governance AG }\end{array}$ & $\begin{array}{l}\text { Rainforest Aboriginal } \\
\text { Consultative Committee }\end{array}$ & $\begin{array}{l}\text { Wet Tropics Regional Agreement, Wet Tropics World } \\
\text { Heritage Protection and Management Act } 1993 \text { (Qld) }\end{array}$ & $\begin{array}{l}\text { Indigenous cultural mapping, } \\
\text { digital databases }\end{array}$ \\
\hline $\begin{array}{l}\text { Indigenous Conservation } \\
\text { Program }\end{array}$ & The Wilderness Society & Native Title and Protected Areas Policy & On-country transmission \\
\hline Mornington Sanctuary & $\begin{array}{l}\text { Australian Wildlife } \\
\text { Conservancy }\end{array}$ & Voluntary conservation plans & Plans based on western science \\
\hline $\begin{array}{l}\text { Wild Rivers Declarations } \\
\text { and Rangers }\end{array}$ & $\begin{array}{l}\text { Queensland Department of } \\
\text { Environment and Resource } \\
\text { Management }\end{array}$ & Wild Rivers Act 2005 (Qld) & $\begin{array}{l}\text { On-country transmission, river } \\
\text { surveys }\end{array}$ \\
\hline
\end{tabular}

theme identification to generate initial propositions, followed by filtering of the propositions through the case studies and the literature, and subsequent further refinement (after Margerum 2008, Robinson 1998). The classification was based on data sources available in 2009, which were updated in 2010, and therefore represents the status of each engagement at that time. As SESs are recognized as highly dynamic
(Walker et al. 2006, Chapin et al. 2010), the classification of each case study in the engagement might be different at a later or earlier stage.

We identified four types of Indigenous engagement in environmental management: Indigenous-governed collaborations (IG); Indigenous-driven co-governance (ICoG); agencydriven co-governance (ACoG) and agency governance (AG). 
Fig. 1. Location of case studies in Australia

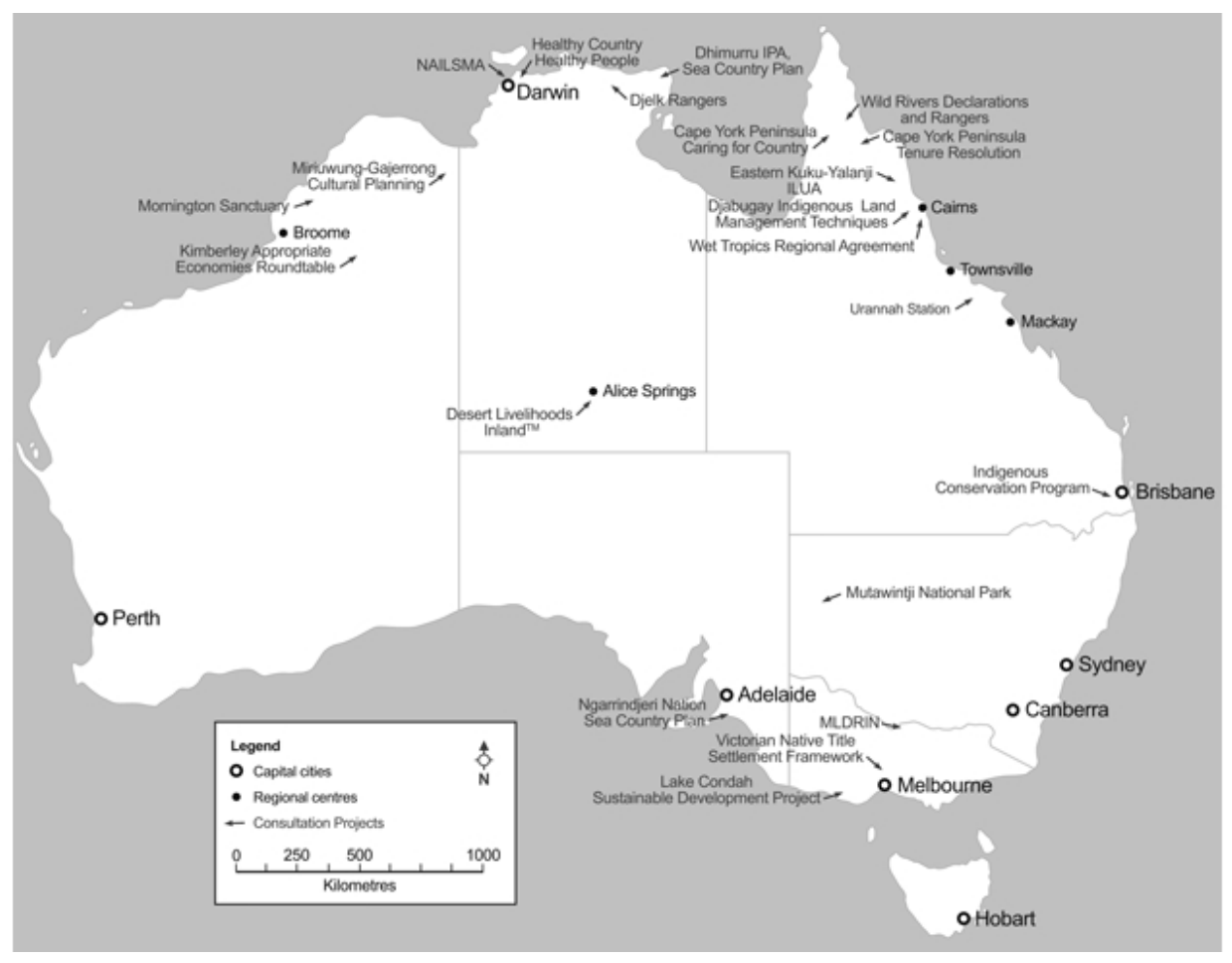

Summaries of differences among the types across the three dimensions and associated categories in our analytical framework are shown in Table 2. The "positions" of each type on axes representing the three dimensions in the analytical framework are shown in Figure 2. We assigned case studies (Table 1) to the type where they demonstrated most consistency with these summaries of differences in all categories within a type (Table 2). The assignments of the case studies within the typology are best viewed as alignments, which may change over time. We addressed two questions relevant to integration of IEK and western science for environmental management: (1) what have been the forms of IEK involved in our case studies; and (2) how has IEK and western science integration been manifested under each typology? We again used techniques of conceptual cluster analysis to consider differences among the case studies regarding manifestations of IEK and western science integration.

\section{RESULTS}

The four types of Indigenous engagement in environmental management

Indigenous-governed collaborations (IGs)

IGs are formulated through Indigenous initiatives, and bring Indigenous peoples together to focus on common environmental issues, actions, and policy agendas. The Northern Australia Indigenous Land and Sea Management Alliance (NAILSMA) and the Murray Lower Darling Rivers Indigenous Nations (MLDRIN) are the two relevant case studies. New Indigenous governance forms are emerging through these collaborations across very large geographical regions. MLDRIN describes itself as a "confederation" of Indigenous nations, providing an alliance of political entities, built from precolonization systems of family connections, trade, and exchange (Weir 2009). Delegates to MLDRIN stress that it does not substitute for the authority of traditional owners, but provides a means of establishing their distinct political status. Indigenous-driven co-governance (ICoG)

ICoG approaches are frequently formulated in response to government initiatives. Indigenous Protected Areas (IPAs), for example, arose in the context of the Australian Government's National Reserve System. However, the power sharing, participation, and intercultural purposes have respected and empowered, rather than undermined, Indigenous interests and authority (Bauman and Smyth 2007). For example, Yolngu involved in Dhimurru Aboriginal Land Management Corporation in North East Arnhem Land, where there is an IPA, have applied symbolism and bonds associated with water to create a Garma theory of knowledge sharing and dialogue to guide environmental management (Robinson and Munungguritj 2001). Agency-driven co-governance (ACoG) 
Table 2. Summaries of differences among types of Indigenous engagement in environmental management

\begin{tabular}{|c|c|c|c|c|}
\hline & $\begin{array}{l}\text { Indigenous-governed } \\
\text { collaborations (IG) }\end{array}$ & $\begin{array}{l}\text { Indigenous-driven co- } \\
\text { governance (ICoG) }\end{array}$ & $\begin{array}{l}\text { Agency-driven co-governance } \\
\text { (ACoG) }\end{array}$ & Agency governance (AG) \\
\hline \multicolumn{5}{|l|}{ Power sharing } \\
\hline $\begin{array}{l}\text { Decision making level } \\
\text { and control }\end{array}$ & $\begin{array}{l}\text { Decision making between } \\
\text { Indigenous agencies; high } \\
\text { Indigenous control }\end{array}$ & $\begin{array}{l}\text { Decision making defined by } \\
\text { Indigenous law and culture and } \\
\text { partner requirements; substantial } \\
\text { Indigenous control }\end{array}$ & $\begin{array}{l}\text { Decision making by agency and } \\
\text { Indigenous people according to } \\
\text { agreed structures, typically } \\
\text { committees; substantial agency } \\
\text { control }\end{array}$ & $\begin{array}{l}\text { Depends on specific project, } \\
\text { usually agency controlled } \\
\text { but local scale provides } \\
\text { Indigenous input }\end{array}$ \\
\hline Rules-definition & $\begin{array}{l}\text { Rules defined by Indigenous } \\
\text { organizations working together } \\
\text { to shape contemporary } \\
\text { Indigenous governance }\end{array}$ & $\begin{array}{l}\text { Rules defined by Indigenous } \\
\text { peoples as constrained by } \\
\text { partner requirements }\end{array}$ & $\begin{array}{l}\text { Rules defined by agency as } \\
\text { constrained by legislative and } \\
\text { policy recognition of Indigenous } \\
\text { rights }\end{array}$ & $\begin{array}{l}\text { Rules defined by agency } \\
\text { constrained only by legally } \\
\text { enforced Indigenous rights }\end{array}$ \\
\hline $\begin{array}{l}\text { Resource cultural } \\
\text { values and property } \\
\text { rights }\end{array}$ & $\begin{array}{l}\text { Resources highly valued by } \\
\text { Indigenous societies; rights } \\
\text { may be defined/constrained } \\
\text { but viewed as open to } \\
\text { transformation }\end{array}$ & $\begin{array}{l}\text { Resources of lesser value in } \\
\text { industrial economy (hinterlands } \\
\text { of first world economies); } \\
\text { Indigenous property rights } \\
\text { strong }\end{array}$ & $\begin{array}{l}\text { Resources of contested value } \\
\text { between industrial and } \\
\text { Indigenous economies; } \\
\text { Indigenous property rights } \\
\text { defined and contained }\end{array}$ & $\begin{array}{l}\text { Resources highly valued by } \\
\text { industrial economy, e.g., } \\
\text { water in heavily used } \\
\text { systems; few Indigenous } \\
\text { property rights }\end{array}$ \\
\hline \multicolumn{5}{|c|}{ Participation } \\
\hline $\begin{array}{l}\text { Participatory processes } \\
\text { and functions }\end{array}$ & $\begin{array}{l}\text { Inclusivity that engages } \\
\text { Indigenous people in new } \\
\text { Indigenous institution building }\end{array}$ & $\begin{array}{l}\text { Inclusivity that engages } \\
\text { Indigenous people in new } \\
\text { environmental institution } \\
\text { building }\end{array}$ & $\begin{array}{l}\text { Indigenous rights-based } \\
\text { negotiation, e.g., for Native } \\
\text { Title Acts, cultural heritage } \\
\text { clearances }\end{array}$ & $\begin{array}{l}\text { Participation through } \\
\text { stakeholder mechanisms, } \\
\text { e.g., committees, projects }\end{array}$ \\
\hline Organizations engaged & $\begin{array}{l}\text { Diverse Indigenous } \\
\text { organizations at multiple } \\
\text { scales }\end{array}$ & $\begin{array}{l}\text { Diverse Indigenous and } \\
\text { nonindigenous organizations at } \\
\text { multiple scales }\end{array}$ & $\begin{array}{l}\text { Government agencies and } \\
\text { NGOs, with defined Indigenous } \\
\text { roles, e.g., Land Councils }\end{array}$ & $\begin{array}{l}\text { Government agencies and } \\
\text { NGOs with defined } \\
\text { environment management } \\
\text { roles }\end{array}$ \\
\hline Coordination & $\begin{array}{l}\text { Cross-regional and cross- } \\
\text { jurisdictional empowerment of } \\
\text { Indigenous groups }\end{array}$ & $\begin{array}{l}\text { Indigenous holistic place-based } \\
\text { community empowerment }\end{array}$ & $\begin{array}{l}\text { Whole-of-government } \\
\text { coordination }\end{array}$ & $\begin{array}{l}\text { "Silo", agency accountability } \\
\text { for specific mandate }\end{array}$ \\
\hline \multicolumn{5}{|c|}{ Intercultural purpose } \\
\hline $\begin{array}{l}\text { Environmental } \\
\text { management project } \\
\text { purposes }\end{array}$ & $\begin{array}{l}\text { Overall purpose of } \\
\text { strengthening Indigenous } \\
\text { society through environmental } \\
\text { management }\end{array}$ & $\begin{array}{l}\text { Multiple purposes, reflecting } \\
\text { Indigenous-centred holistic } \\
\text { community planning }\end{array}$ & $\begin{array}{l}\text { Multiple purposes, reflecting } \\
\text { outcomes of negotiated } \\
\text { agreements }\end{array}$ & $\begin{array}{l}\text { Usually single or dual } \\
\text { purpose, managing specific } \\
\text { threats, species or areas }\end{array}$ \\
\hline $\begin{array}{l}\text { Purpose of Indigenous } \\
\text { roles }\end{array}$ & $\begin{array}{l}\text { Expression of inherent rights } \\
\text { and responsibilities }\end{array}$ & $\begin{array}{l}\text { Reconciliation, long-term, } \\
\text { lasting resolution of issues }\end{array}$ & $\begin{array}{l}\text { Equity plus recognition of } \\
\text { specifically defined rights }\end{array}$ & $\begin{array}{l}\text { Equity with other } \\
\text { stakeholders in } \\
\text { environmental management }\end{array}$ \\
\hline $\begin{array}{l}\text { Purpose of Indigenous } \\
\text { development }\end{array}$ & $\begin{array}{l}\text { Indigenous modernity, people } \\
\text { resist, accommodate, and } \\
\text { reshape interventions }\end{array}$ & $\begin{array}{l}\text { Indigenous empowerment and } \\
\text { community development }\end{array}$ & $\begin{array}{l}\text { Human capability development, } \\
\text { sustainable livelihoods through } \\
\text { deployment of assets }\end{array}$ & $\begin{array}{l}\text { Development as } \\
\text { modernization and } \\
\text { technology transfer }\end{array}$ \\
\hline Capacity-building & $\begin{array}{l}\text { Focus on building trust and } \\
\text { relationships between diverse } \\
\text { Indigenous groups }\end{array}$ & $\begin{array}{l}\text { Focus on Indigenous and } \\
\text { nonindigenous functionality in } \\
\text { both Indigenous and settler } \\
\text { society }\end{array}$ & $\begin{array}{l}\text { Focus on Indigenous } \\
\text { functionality in settler society } \\
\text { and cross-cultural training for } \\
\text { nonindigenous people }\end{array}$ & $\begin{array}{l}\text { Focus on training Indigenous } \\
\text { peoples to ensure } \\
\text { functionality in settler- } \\
\text { society }\end{array}$ \\
\hline
\end{tabular}

ACoG approaches usually arise from formal processes to recognize and define Indigenous rights, such as through native title or recognition of Aboriginal joint management of protected areas. Agency-driven models require the power to sit within the organization, through mechanisms such as boards or committees of management. Indigenous governance mandates sharing power beyond organizations and into wider networks of families and communities (Smith and Hunt 2008). In the ACoG types, the agency seeks to meet the expectations of a wide array of stakeholders, such as conservation groups, fishers, tourism operators and others. The complexity and competition within such an institution may crowd out Indigenous perspectives. Agency governance (AG)

AG approaches regard Indigenous people as a stakeholder sector, similar to farmers or industry actors, rather than as a group requiring a different approach associated with their claims to a distinct political status within the nation-state. For example, The Wilderness Society's (TWS) Indigenous Conservation Program places their goals of environmental preservation to the fore in engagement with Indigenous people, and seeks to build alliances with Indigenous people 
Fig. 2. Position of types on the three axes, namely participation, intercultural purpose, and power sharing, and the zone of convergence of western science and Indigenous Ecological Knowledge (IEK) that emerges in the Indigenous-governed and Indigenous-driven co-governed types

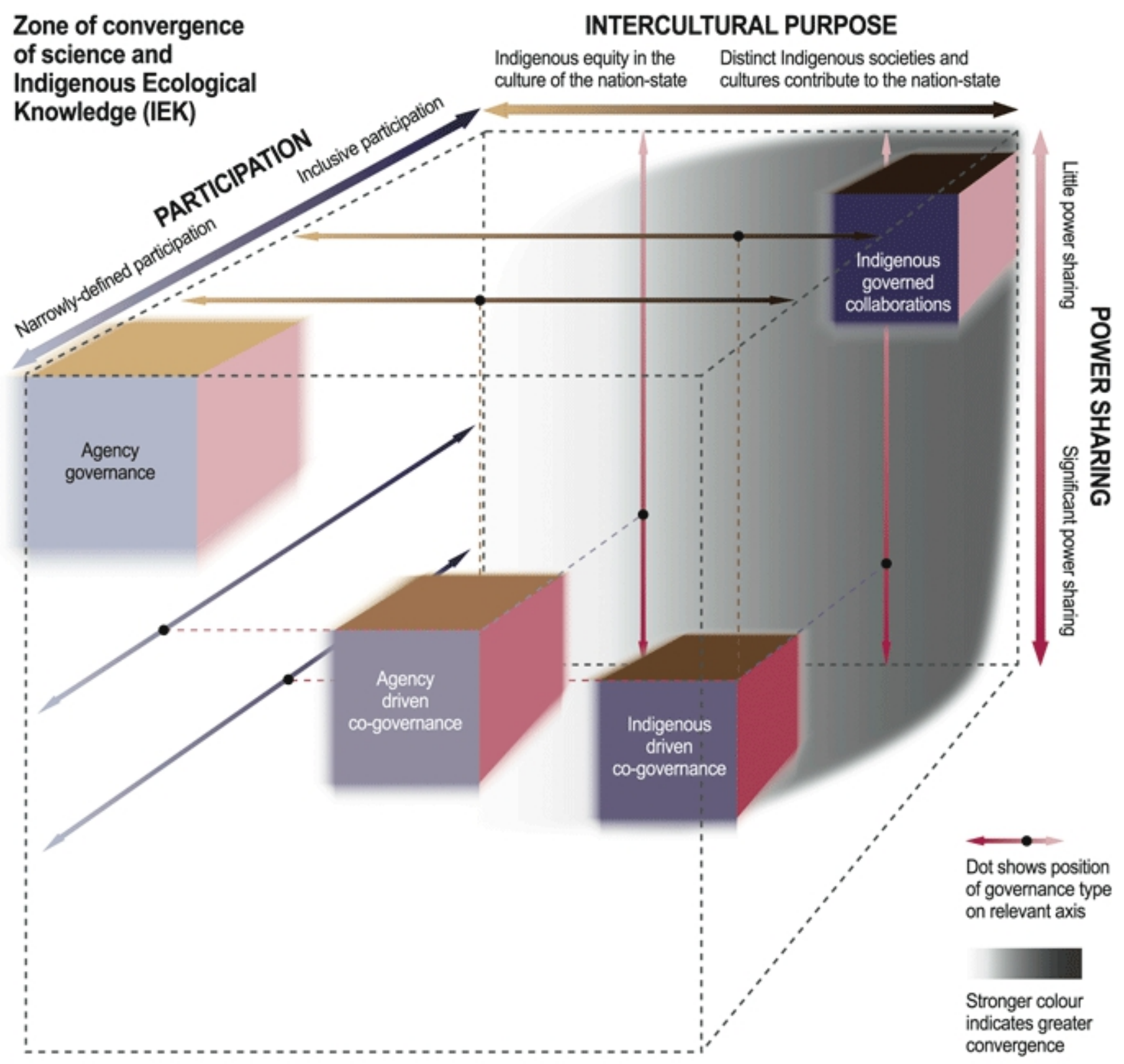

who support their environmental goals, similar to alliances built with farmers or industry actors (Pickerill 2008). Nevertheless, through initiatives such as TWS and Chuulangan Aboriginal Corporation Cooperation Agreement, Indigenous peoples and TWS have established co-governance arrangements for specific projects (Claudie and Esposito 2005).

\section{Illustrative examples of differences between the types}

Table 2 summarizes the difference between the types across the analytical categories, and Table 3 presents examples from the case studies that illustrate these differences. Space precludes presenting examples from all 40 cells in the matrix generated by the four types and ten categories. Instead, we describe the spectrum across the three dimensions of power 
Table 3. Illustrative examples of the summarized differences among the case studies according to the categories of analysis for the typology

\begin{tabular}{ll}
\hline \hline $\begin{array}{l}\text { Typology } \\
\text { category }\end{array}$ & Summarized difference among types
\end{tabular}

\section{Power sharing}

Decision ICoG: Decision making defined by

making level Indigenous law and culture and partner

and control requirements; substantial Indigenous control

ACoG: Decision making by agency and Indigenous people according to agreed structures, typically committees; substantial agency control

Rules- $\quad$ ICoG: Rules defined by Indigenous definition peoples as constrained by partner requirements

Resource cultural values and property rights

\section{Participation} Participatory processes and functions

Coordination

ACoG: Resources of contested value between industrial and Indigenous economies; Indigenous property rights defined and contained

AG: Resources highly valued by industrial economy, e.g., water in heavily used systems; few Indigenous property rights

ACoG: Indigenous rights-based negotiation, e.g., for Native Title Acts, cultural heritage clearances

ICoG: Inclusivity that engages

Indigenous people in new environmental institution-building

IG: Inclusivity that engages Indigenous people in new Indigenous institutionbuilding

ACoG: Whole-of-government coordination

ICoG: Indigenous holistic place-based community empowerment

\section{Intercultural purpose}

Environmental AG: Usually single or dual purpose, management managing specific threats, species or purposes

ICoG: Multiple purposes, reflecting Indigenous-centred holistic community planning

Purpose of Indigenous roles
ACoG: Equity plus recognition of specifically defined rights

ICoG: Reconciliation, long-term, lasting resolution of issues
Miriuwung-Gajerrong Cultural Planning: the Ord Final Agreement established a formal committee with a majority of Miriuwung-Gajerrong people as the decision making body. The Yawoorroong Miriuwung Gajerrong Yirrgeb Noong Dawang Aboriginal Corporation supports the committee with processes that empower localized decision making by Dawang, through an Indigenous governance structure.

Cape York Tenure Resolution: process is headed by a decision making committee comprising three State Government Ministers, the Australian Conservation Foundation, The Wilderness Society, Balkanu and the Cape York Land Council. Decisions on land tenure outcomes are underpinned by Indigenous Land Use Agreements, and require negotiation and Indigenous consent, thereby empowering Indigenous law and custom.

Djelk Rangers: rules within Bawinanga Aboriginal Corporation, which host the Djelk Rangers, are mediated within the informal institution of the "smoko" room. Local Aboriginal elites with power based on seniority, Indigenous knowledge and customary authority negotiate with Aboriginal neo-elites whose power derives from modernizing projects, including the duties of the Djelk Rangers to protect biodiversity within parameters set by their government funding agencies.

Eastern Kuku-Yalanji ILUA: focuses on recognition and regulation of people's native title rights as custodians and managers of traditional country within highly contested tropical landscapes, while delivering statutory Aboriginal ownership of some areas of land.

Wild Rivers: the marginalization of Indigenous peoples from Wild Rivers decision making reflects legislative regimes that have placed the control and regulation of water with the Crown and its agencies.

Wet Tropics Regional Agreement: Interim Negotiating Forum constituted an Aboriginal Negotiating Team and a Government Negotiating Team.

Dhimurru: stresses their pride in their model of partnerships founded in Yolngu culture and the customary ways Yolngu care for country. This requirement of Indigenous agency to drive participation has resulted in the new environmental institution of a formal IPA Advisory Group of government and other stakeholders.

Murray Lower Darling River Indigenous Nations: partnerships all contain acknowledgements of the traditional owners, their specific relationships with country, and the importance of their decision making structures.

Healthy Country Healthy People: multiple departments coordinate delivery across environmental, socio-cultural and economic goals through a Steering Committee of government officers, with Indigenous organizations in an advisory role.

Djabugay Indigenous land management techniques: arise from a perspective that places an Indigenous world view at the centre. Eleven aspects of Indigenous land management emanate from this centre: tradition and Laws/lores; elders; spiritual; land and sea country; employment; youth; health; obligation and responsibility; community rangers; education; and cultural training.

TWS Indigenous Conservation Program: describes their purpose in working with Indigenous traditional owners as to achieve protection and management of Cape York Peninsula and the return of homelands to the control and management of its traditional owners;

Ngarrindjeri Nation Sea Country Plan: has multiple goals, ranging across healthy people, healthy country, equitable benefit sharing, health and spiritual well-being of Ngartjis (special animals), ongoing occupation of country and respect for law.

Urannah Station: Indigenous engagement at Urannah Station, part of the Indigenous Land Corporation's (ILC) program of works, is aimed at achieving equity for Indigenous Australians through halving the employment gap within a decade.

Victorian Native Title Settlement Framework: explicitly recognizes reconciliation within its objects, which encompass social and economic upliftment, grievance resolution and rights recognition. 
Purpose of Indigenous development

AG: Development as modernization and technology transfer

ICoG: Indigenous empowerment and community development

Capacity- ICoG: Focus on Indigenous and nonbuilding Indigenous functionality in both Indigenous and settler society

IG: Focus on building trust and relationships among diverse Indigenous groups
Mornington Station: through the Ecofire Project, the Australian Wildlife Conservancy facilitates involvement of Indigenous community members, including provision of training in prescribed fire management using aerial incendiaries provided by the Fire and Emergency Services Authority.

Kimberley Appropriate Economies Roundtable: promoted theories of ecological economics and Indigenous governance, aimed at empowering Indigenous peoples and other citizens to build their own planning, decision making and governance capacity.

Lake Condah Sustainable Development Project: a sophisticated approach to simultaneously build Indigenous and nonindigenous capacity and pathways to sustainability has been developed through Lake Condah Learning.

Northern Australia Indigenous Land and Sea Management Alliance: regularly hosts events that bring together Indigenous peoples from across the north to build common agendas, such as the Northern Australian Indigenous Experts Water Futures Forum. sharing, participation, and intercultural purpose, with reference to the illustrative examples presented in Table 3.

\section{Power sharing}

The spectrum from little power sharing in IG and AG types (in which Indigenous peoples and agencies retain power respectively), to substantial power sharing in ICoG and ACoG, both determines and reflects the arrangements for decision making, rules-definition, and resource cultural values and property rights (Figure 2). Table 3 illustrates the differences between decision making within the ICoG type (Miriuwung Gajerrong Cultural Planning Framework), which promotes Indigenous governance, and the ACoG type (Cape York Peninsula Tenure Resolution), which promotes negotiated agreement. The complexity of rules-definition in ICoG is illustrated by the Djelk Rangers (ICoG) informal forum for traditional and modernizing influences to negotiate ascendancy (Altman 2008).

In relation to resource values and rights, the power sharing spectrum ranges from situations in which the Indigenous rights are insecure and the natural resource highly valued in industrial economies, to those in which Indigenous peoples have secured recognition of ownership of resources, generally of lesser value in industrial economies, through native title or other legislation. Table 3 illustrates the difference between the Eastern Kuku-Yalanji (ACoG), with contested resources (Stork et al. 2008), and the Wild Rivers case (AG), where the control of water has been vested in agencies of the Australian nation-state (Jackson and Altman 2009). Nevertheless, some ICoG types are emerging even where Indigenous resource rights are insecure, reflecting a focus on the broader reconciliation context; the Victorian Native Title Settlement Framework is an example.

\section{Participation}

Participation ranges on a spectrum from inclusive to narrowly defined across the three categories of participatory processes, organizations engaged, and coordination approaches (Figure 2). The Wet Tropics Regional Agreement illustrates the ACoG types' participatory focus on formal processes and those with specifically defined interests (Table 3). Dhimurru's non-
Indigenous Advisory Group illustrates the ICoG focus on inclusivity that builds new environmental institutions, whereas MLDRN illustrates the IG focus on new Indigenous institutions (Table 3). The Indigenous Water Policy Group convened by NAILSMA is another example of new Indigenous institution building (Jackson and Altman 2009). Approaches to coordination vary from none in the AG types ("the silo") through whole-of-government approaches (defined as specific strategies to link government agencies' roles and overcome the silos), to Indigenous holistic coordination in the IG types. Healthy Country Healthy People (ACoG) illustrates whole-of-government coordination by government agencies developing shared approaches to delivering their sectoral goals. The Djabugay (ICoG) case study illustrates the Indigenous holistic approach to coordination through Indigenous worldviews of the inherent linkages between Indigenous people, the environment, and Indigenous culture (Talbot 2005).

\section{Intercultural purpose}

Approaches to intercultural purpose vary across a spectrum from IG's focus on advancing distinct Indigenous societies' and cultures' contributions to the nation-state, to AG's focus on achieving Indigenous equity within the culture of the nation-state (Figure 2). Indigenous people consistently highlight the holistic nature of their engagement and knowledge, of which environmental purposes form part. Government environmental agencies, on the other hand, usually have specific responsibilities mandated by legislation such as threatened species management, without links to policy arising from other legislation, such as education or business development (Boxelaar et al. 2006). Environmental nongovernment organizations (ENGOs) similarly have specific mandates reflected in their organizational structures and fundraising appeals. Table 3 illustrates these differences between the confined purposes of the TWS Indigenous Conservation Program (AG), and the Ngarrindjeri's (ICoG) broad goals across healthy people, healthy country, spiritual well-being and more. The purposes of Indigenous roles vary similar across a spectrum from AG's concern with equity, as illustrated by the ILC's program at Urranah Station, to ICoG's 
Table 4. Analysis of manifestations of Indigenous Ecological Knowledge (IEK) and science integration according to governance types

\begin{tabular}{|c|c|c|c|c|}
\hline $\begin{array}{l}\text { Dimensions of knowledge } \\
\text { integration }\end{array}$ & $\begin{array}{l}\text { Means of integration } \\
\text { between IEK and science }\end{array}$ & $\begin{array}{l}\text { Appearance of amalgams } \\
\text { representing new, converged } \\
\text { forms of IEK and science } \\
\text { knowledge }\end{array}$ & $\begin{array}{l}\text { Means of managing the } \\
\text { integrity of IEK }\end{array}$ & $\begin{array}{l}\text { Means of integration of IEK } \\
\text { and science into } \\
\text { environmental management }\end{array}$ \\
\hline \multicolumn{5}{|l|}{ Governance type } \\
\hline $\begin{array}{l}\text { Indigenous-governed } \\
\text { collaborations }\end{array}$ & $\begin{array}{l}\text { Collaboration between IEK } \\
\text { and science; distinction } \\
\text { between the two blurred }\end{array}$ & $\begin{array}{l}\text { Amalgams emphasized, e.g., } \\
\text { ethno-ecology, ethno- } \\
\text { science; digital data-bases } \\
\text { with both IEK and science }\end{array}$ & $\begin{array}{l}\text { Indigenous law and custom; } \\
\text { exercise of traditional } \\
\text { authority; tight contemporary } \\
\text { governance structures } \\
\text { specified }\end{array}$ & $\begin{array}{l}\text { Combination of western } \\
\text { science and Indigenous } \\
\text { knowledge tools, principles of } \\
\text { application specified }\end{array}$ \\
\hline $\begin{array}{l}\text { Indigenous-driven co- } \\
\text { governance }\end{array}$ & $\begin{array}{l}\text { Collaboration between IEK } \\
\text { and science; joint projects as } \\
\text { means of integration }\end{array}$ & $\begin{array}{l}\text { Amalgams utilized, e.g., } \\
\text { maps that amalgamate } \\
\text { painting of Indigenous } \\
\text { knowledge with western } \\
\text { scientific data }\end{array}$ & Ditto & $\begin{array}{l}\text { Simultaneous application of } \\
\text { both into environmental } \\
\text { management; principles } \\
\text { sometimes specified }\end{array}$ \\
\hline $\begin{array}{l}\text { Agency-driven co- } \\
\text { governance }\end{array}$ & $\begin{array}{l}\text { "Validation" of IEK by } \\
\text { science; separate } \\
\text { documentation of IEK and } \\
\text { science }\end{array}$ & $\begin{array}{l}\text { Jointly authored scientific } \\
\text { papers; reports targeting both } \\
\text { scientific and Indigenous } \\
\text { audiences }\end{array}$ & $\begin{array}{l}\text { Protocols; agreements; } \\
\text { respect for Indigenous law; } \\
\text { informed consent }\end{array}$ & $\begin{array}{l}\text { Negotiated approaches; } \\
\text { Indigenous emphasis on } \\
\text { preventing cultural } \\
\text { appropriation }\end{array}$ \\
\hline Agency governance & $\begin{array}{l}\text { Separation of IEK and } \\
\text { science; little or no } \\
\text { documentation of IEK }\end{array}$ & No amalgams identified & $\begin{array}{l}\text { Loose, not specified; e.g., } \\
\text { involvement of elders in on- } \\
\text { country knowledge transfer }\end{array}$ & $\begin{array}{l}\text { Management based on western } \\
\text { science; IEK present but its } \\
\text { utilization kept separate }\end{array}$ \\
\hline
\end{tabular}

recognition of the broader context of reconciliation, as within the Victorian Native Title Settlement Framework (Table 3).

This spectrum of intercultural purposes is associated with diversity in theories about development for and with Indigenous peoples (Hunt 2008). The continuum ranges from development as modernization and technology transfer (Sillitoe and Marzano 2009), through human capability development and asset deployment (Sen 2005, Davies et al. 2008), to concepts of empowerment and participatory practice (Borrini-Feyerabend et al. 2004, Davies and Holcombe 2009), community development, Indigenous hybrid economies (Altman 2007) and Indigenous "modernities" as hybrid responses based on Indigenous cultures (Robins 2003, Walker et al. 2007). Table 3 illustrates the differences between Mornington Station's (AG) focus on transfer of modern technologies for fire management, and the Kimberley Appropriate Economies Roundtable (ICoG) focus on empowerment of Indigenous peoples through their own planning.

Differences in terms of whose capacities most need improvement, the Indigenous or non-Indigenous peoples, emerged across the case studies. AG types focus on improving Indigenous capacities to operate in "settler societies", where settlers are defined as non-Indigenous peoples and their descendants in Australia who have multicultural origins. ACoG and ICoG types recognize the need to improve the capacity of both Indigenous and non-Indigenous people to operate across Indigenous and settler societies, while IG focuses on building capacity of Indigenous peoples. Table 3 illustrates differences between the Lake Condah Sustainable Development (ICoG) focus on both Indigenous and nonIndigenous capacity, and NAILSMA's (IG) attention to building capacity of Indigenous peoples.

\section{Manifestations of IEK and western science integration}

Virtually all case studies included trips to the countryside where intergenerational and cross-cultural IEK transfer occurred regarding Indigenous cultural sites, bush foods, location of cultural boundaries, storylines and places, and historical events. Many documents included Indigenous art and language names for key features and biota (Table 1). Systematic documentation of IEK through digital video databases and spatially-located mapping of Indigenous use and occupancy is underway in several of our case studies across the IG, ICoG, and ACoG types, including NAILSMA, MLDRIN, Ngarrindjeri, and the Wet Tropics (Hill and Williams 2009, Standley et al. 2009, Tobias 2010). Nevertheless, we found differentiation between the types on four dimensions: methods for integration between IEK and western science; appearance of amalgams representing new, converged forms of IEK and science knowledge; means for managing the integrity of IEK; and means for integration of IEK and science into environmental management (Table 4).

The IG and ICoG types concentrate on collaboration between IEK and western science, with an emphasis on amalgams such as ethnoecology leading to some blurring of the distinction between the two. Amalgamated forms are often distinctly 
Indigenous, such as the highly innovative visual and spatial modes of communication, including paintings of country on scientifically-derived vegetation maps, arising from IPAs (Hill et al. 2011). Despite this convergence, IG and ICoG pay great attention to Indigenous methods for ensuring the integrity of IEK. For example, NAILSMA is engaged in advocacy for Indigenous rights and titles over IEK. Yolngu specify in the Dhimurru IPA that all decisions must be made by those who own knowledge under customary law. This concern for integrity is reflected in recognition that both knowledge systems need to be applied to environmental management. MLDRIN, for example, expresses a specific principle: "that Indigenous science and Western science each have their own value and role in caring for country" (Weir 2009:116).

ACoG and AG types typically maintain the distinction between IEK and western science, through separate documentation initiatives, and clearly specified interactions, such as "validation" of IEK by science (Evans et al. 2009). New amalgams, where they do appear, are more clearly in the western science domain, for example jointly authored papers or reports written to target both technical and Indigenous audiences. The AG and ACoG types do not focus as strongly on ensuring the integrity of IEK; where respect for Indigenous law is articulated, practical means of enabling this are often unclear. The emphasis is on agreements about IEK utilization, rather than customary law maintenance and enhancement. The collection of IEK often does not feed into the agency environmental management strategies. In the Wet Tropics Regional Agreement example, an Aboriginal cultural mapping project using digital video and spatially-located data under traditional owner control is not integrated into management (Roder 2008). Aboriginal people in the Wet Tropics are wary of science, defining "scientists" as "knowledge takers" in the Regional Agreement, and adopting protocols aimed at controlling, rather than facilitating access to and integration of, their IEK (Wet Tropics Management Authority et al. 2005). Figure 2 highlights the zone of convergence of IEK and western science that emerges more strongly in the IG and ICoG types. Nevertheless, SESs are recognized as dynamic (Walker et al. 2006), and we detected increasing convergence in some case studies, although it was beyond the resources of the project to systematically examine change over time. For example, an Indigenous-driven ethnobotany initiative is a recent manifestation in the Wet Tropics (Hill et al. 2011), some distinctly Indigenous amalgams have appeared in association with the Desert Livelihoods initiative (Desert Knowledge Cooperative Research Centre 2009), and The Wilderness Society has supported development of seasonal calendars, recognized as a valuable tool for knowledge integration (O'Connor and Prober 2010, Prober et al. 2011). We hypothesize that Indigenous peoples' utilization of opportunities for influence will shift governance toward a greater Indigenous role over time.

\section{DISCUSSION}

Our analysis of manifestations of knowledge integration suggests that IG and ICoG types provide better prospects than ACoG and AG types for integration and convergence of IEK and western science. We recognize that both the concept of IEK and approaches to integration are highly contested. Scientists call for greater efforts in the definition and validation of the integrity of IEK knowledge claims, and some Indigenous groups have also sought validation of their IEK knowledge claims by science (Evans et al. 2009, Gratani et al. 2011). Other Indigenous people resist scientific efforts to integrate with IEK as a result of concerns that power relations embedded in IEK projects will further marginalize their interests (Smith 1999, Agrawal 2002, Davis and Ruddle 2010). Nevertheless, connections between ownership of IEK and ownership of land and sea in Australian Indigenous cultures trigger significant responsibilities for maintaining control (Rose 1994). This issue of control emerged as linked to knowledge integrity in our analysis; IG and ICoG types provide the customary law authority necessary for Indigenous people to develop innovations that deploy their IEK while maintaining its integrity. Supporting Indigenous governance without, or with limited, requirement for power sharing with other agencies sustains the distinct Indigenous cultural purposes underpinning IEK, and benefits knowledge integration (Figure 2).

Previous experiences in the integration of IEK with western science have demonstrated that promoting a diverse cultural foundation can enhance the social-ecological system attributes associated with sustainability (Berkes et al. 2000, Folke 2004, Walker and Salt 2006). Our analysis that Indigenous governance provides better prospects for such knowledge integration potentially links Indigenous governance with sustainability in SES. Such links have been suggested previously. Delegates at an Australian conference on Indigenous governance in 2002 concluded that socioeconomic sustainability for Indigenous peoples only improves when real decision making power is vested in their communities through effective governing institutions that reflect Indigenous cultural values and beliefs (Reconciliation Australia 2002). Policy trials delivering greater Indigenous governance over welfare and education are now underway in Cape York Peninsula, reversing a trend elsewhere in Australia for policy interventions that remove Indigenous control (Altman and Johns 2008, Lane and Williams 2009). The potential linkages between Indigenous governance and sustainability in SES, and the role of knowledge integration in mediating any such linkages, are worthy of further investigation.

Application of the typology is likely to enable both better design and more robust analysis of Indigenous engagement in diverse environmental management contexts. Practitioners should find the AG types suitable to meet a specific agency mandate and accountability where engagement of the 
Indigenous polity and culture is not critical (for example, agency mandates discussed in Hill and Williams 2009, Ross et al. 2009). For researchers, the theoretical underpinnings of technology transfer and development as modernization should provide an appropriate basis for analysis (Servaes and Obijiofor 2007). On the other hand, the ICoG type's characteristics of Indigenous time frames, traditional decision making, and coordination would challenge a situation in which the accountability requirements of the agency necessitate that projects meet inflexible time frames and pre-determined outcomes. The theoretical underpinnings of Indigenous empowerment, hybrid economies, and community development should provide an appropriate basis for analysis of outcomes (Altman 2007, Wilmsen et al. 2008, Davies and Holcombe 2009). Nevertheless, all SESs are recognized as dynamic (Walker et al. 2006), including our case studies, and this dynamism will influence application of the typology. For example, we hypothesize that Indigenous influences on governance increase over time, as previously discussed. Further research is warranted to test the relative advantages and disadvantages of consistency within each type, and to analyze the driving factors and the conditions to which they are best suited, and which may change with time.

\section{CONCLUSION}

Our typology, based on analysis of 21 Australian case studies of Indigenous engagement in environment management, helps to distil the impact of governance on integration of IEK and western science in the management of SES. We differentiated four types of engagement: Indigenous-governed collaborations (IG); Indigenous-driven co-governance (ICoG); agencydriven co-governance (ACoG) and agency governance (AG). Our analysis of the influence of type on knowledge integration suggests that IG and ICoG types provide better prospects than ACoG and AG types. The control necessary for Indigenous people to deploy their IEK while maintaining its integrity, and avoiding risks of the deployment being used to further marginalize their interests provides the underpinning logic. Ownership of IEK is connected to ownership of, and responsibility for, land and sea in Australian Indigenous societies (Rose 1994). Supporting Indigenous governance without, or with limited, requirement for power sharing with other agencies sustains the distinct Indigenous cultural purposes underpinning IEK, and benefits knowledge integration (Figure 2). The linkage between Indigenous governance and social-ecological system sustainability, suggested by this research, adds weight to the growing body of evidence highlighting culturally diverse governance as critical to sustainability, and is worthy of further investigation (Berkes 2004, Folke 2004). We argue that consistency of design across the categories within one type is likely to enable both better practice and more robust analysis of Indigenous engagement in diverse environmental management contexts. We advocate the application of the typology by policy makers and researchers, and look forward to future evaluations of its general effectiveness in guiding practitioners and researchers of scientific and Indigenous knowledge integration in environmental management.

Responses to this article can be read online at: http://www.ecologyandsociety.org/voll7/iss1/art23/ responses/

\section{Acknowledgments:}

The authors would like to acknowledge the fine work of numerous people over many years occurring within the case studies profiled in this study. We thank the Marine and Tropical Science Research Facility and CSIRO's Building Resilient Australian Biodiversity Assets Theme for the generous support that enabled the conduct of this comparative analysis. Marcus Finn, Iris Bohnet, and two anonymous reviewers' helpful comments on earlier versions greatly improved the manuscript. We would like to particularly thank the Special Edition Editors Jocelyn Davies, Erin Bohensky, and James Butler for invaluable advice, guidance, and support in bringing this paper to completion. The ideas expressed in this paper are those of the authors alone.

\section{LITERATURE CITED}

Aboriginal \& Torres Strait Islander Social Justice Commissioner (ATSISJC). 2009. Social justice report 2008. Australian Human Rights Commission and the ATSISJC, Sydney, Australia.

Agius, P., T. Jenkin, S. Jarvis, R. Howitt, and R. Williams. 2007. (Re)asserting indigenous rights and jurisdictions within a politics of place: transformative nature of native title negotiations in South Australia. Geographical Research 45:194-202. http://dx.doi.org/10.1111/j.1745-5871.2007.00451. $\underline{\mathrm{X}}$

Agrawal, A. 2002. Indigenous knowledge and the politics of classification. International Social Science Journal 54:287-297.

Altman, J. C. 2007. Alleviating poverty in remote indigenous Australia: the role of the hybrid economy. Topical issue 10/2007. Centre for Aboriginal Economic Policy Research, Australian National University, Canberra, Australia.

Altman, J. C. 2008. Different governance for difference: the Bawinanga Aboriginal Corporation. Pages 177-203 in J. Hunt, D. Smith, S. Garling, and W. Sanders, editors. Contested governance. culture, power and institutions in indigenous Australia. Research Monograph No. 29. Australian National University, Canberra, Australia.

Altman, J. C., G. J. Buchanan, and L. Larsen. 2007. The environmental significance of the indigenous estate: natural 
resource management as economic development in remote Australia. Centre for Aboriginal Economic Policy Research, Australian National University, Canberra, Australia.

Altman, J. C., and M. Johns. 2008. Indigenous welfare reform in the Northern Territory and Cape York: a comparative analysis. CAEPR Working Paper No. 44. Centre for Aboriginal Economic Policy Research, Australian National University (ANU), Canberra, Australia.

Arnstein, S. R. 1969. A ladder of citizen participation. American Institute of Planners Journal 35:216-224. http://dx. doi.org/10.1080/01944366908977225

Australian Institute of Health and Welfare (AIHW). 2010. Australia's health 2010. Australia's health series no. 12. Cat. No. AUS 122. AIHW, Canberra, Australia.

Bakker, K., and G. Bridge. 2006. Material worlds? Resource geographies and the 'matter of nature'. Progress in Human Geography 30:5-27. http://dx.doi.org/10.1191/0309132506ph5880a

Ballard, H. L., M. E. Fernandez-Gimenez, and V. E. Sturtevant. 2008. Integration of local ecological knowledge and conventional science: a study of seven community-based forestry organizations in the USA. Ecology and Society 13 (2):37. [online] URL: http://www.ecologyandsociety.org/vol13/ iss $2 / \operatorname{art} 37 /$

Bauman, T., and D. M. Smyth. 2007. Indigenous partnerships in protected area management in Australia: three case studies. Australian Institute of Aboriginal and Torres Strait Islander Studies, Canberra, Australia.

Berkes, F. 2004. Rethinking community-based conservation. Conservation Biology 18:621-630. http://dx.doi.org/10.1111/ j.1523-1739.2004.00077.x

Berkes, F., J. Colding, and C. Folke. 2000. Rediscovery of traditional ecological knowledge as adaptive management. Ecological Applications 10:1251-1261. http://dx.doi.org/10.1 890/1051-0761(2000)010[1251:ROTEKA]2.0.CO;2

Bohensky, E. L., and Y. Maru. 2011. Indigenous knowledge, science, and resilience: what have we learned from a decade of international literature on "integration". Ecology and Society 16(4):6. http://dx.doi.org/10.5751/ES-04342-160406

Borrini-Feyerabend, G., M. Pimbert, M. T. Farvar, A. Kothari, and Y. Renard. 2004. Sharing power. Learning by doing in comanagement of natural resources throughout the world. International Institute for Environment and Development (IIED) and International Union for the Conservation of Nature (IUCN)/ Commission on Environmental, Economic and Social Policy (CEESP)/ Co-management Working Group (CMWG), Centre for Sustainable Development (CENESTA), Tehran, Iran.
Boxelaar, L., M. Paine, and R. Beilin. 2006. Community engagement and public administration: Of silos, overlays and technologies of government. Australian Journal of Public Administration 65:113-126. http://dx.doi.org/10.1111/j.14678500.2006.00476.x

Carlsson, L., and F. Berkes. 2005. Co-management: concepts and methodological implications. Journal of Environmental Management 75:65-76. http://dx.doi.org/10.1016/j.jenvman.2 $\underline{004.11 .008}$

Carpenter, S. R., H. A. Mooney, J. Agard, D. Capistrano, R. S. DeFries, S. Diaz, T. Dietz, A. K. Duraiappah, A. OtengYeboah, H. M. Pereira, C. Perrings, W. V. Reid, J. Sarukhan, R. J. Scholes, and A. Whyte. 2009. Science for managing ecosystem services: beyond the Millennium Ecosystem Assessment. Proceedings of the National Academy of Sciences of the United States of America 106:1305-1312. http://dx.doi. org/10.1073/pnas.0808772106

Chapin, F. S., III, S. R. Carpenter, G. P. Kofinas, C. Folke, N. Abel, W. C. Clark, P. Olsson, D. M. S. Smith, B. Walker, O. R. Young, F. Berkes, R. Biggs, J. M. Grove, R. L. Naylor, E. Pinkerton, W. Steffen, and F. J. Swanson. 2010. Ecosystem stewardship: sustainability strategies for a rapidly changing planet. Trends in Ecology \& Evolution 25:241-249. http://dx. doi.org/10.1016/j.tree.2009.10.008

Claudie, D., and A. Esposito. 2005. Chuulangun sign agreement. Kantri Laif 2:1-2.

Cundill, G., and C. Fabricius. 2010. Monitoring the governance dimension of natural resource co-management. Ecology and Society 15(1):15. [online] URL: http://www.eco logyandsociety.org/vol15/iss1/art15/

Davidson-Hunt, I. J., and O'Flaherty. 2007. Researchers, indigenous peoples, and place-based learning communities. Society and Natural Resources 20:291-305. http://dx.doi.org/ $\underline{10.1080 / 08941920601161312}$

Davies, J. 2003. Contemporary geographies of indigenous rights and interests in rural Australia. Australian Geographer 34:19-45. http://dx.doi.org/10.1080/00049180320000066137

Davies, J., and S. Holcombe. 2009. Desert knowledge: integrating knowledge and development in arid and semi-arid drylands. GeoJournal 74:363-375. http://dx.doi.org/10.1007/ s10708-009-9279-4

Davies, J., J. White, A. Wright, Y. Maru, and M. LaFlamme. 2008. Applying the sustainable livelihoods approach in Australian desert Aboriginal development. The Rangeland Journal 30:55-65. http://dx.doi.org/10.1071/RJ07038

Davis, A., and K. Ruddle. 2010. Constructing confidence: rational skepticism and systematic enquiry in local ecological 
knowledge research. Ecological Applications 20:880-894. http://dx.doi.org/10.1890/09-0422.1

Dawson, T., M. Rounsevell, T. Kluvánková-Oravská, V. Chobotová, and A. Stirling. 2010. Dynamic properties of complex adaptive ecosystems: implications for the sustainability of service provision. Biodiversity and Conservation 19:2843-2853. http://dx.doi.org/10.1007/s1053 1-010-9892-Z

Desert Knowledge Cooperative Research Centre (CRC). 2009. Apmeraltye ingkerreke: People of one land, all together. Record of conference session from Regional Arts Australia art at the heart, 2nd to 4th October, 2008. Desert Knowledge CRC, Alice Springs, Australia.

Dietz, T., E. Ostrom, and P. C. Stern. 2003. The struggle to govern the commons. Science 302:1907-1912. http://dx.doi.o rg/10.1126/science.1091015

Evans, L., H. Scott, K. Muir, and J. Briscoe. 2009. Effective intellectual property protection of traditional knowledge of plants and their uses: an example from Australia. GeoJournal 74:391-401. http://dx.doi.org/10.1007/s10708-008-9229-6

Fernandez-Gimenez, M. E., H. P. Huntington, and K. J. Frost. 2006. Integration or co-optation? Traditional knowledge and science in the Alaska Beluga Whale Committee. Environmental Conservation 33:306-315. http://dx.doi.org/10 $.1017 / \mathrm{S} 0376892906003420$

Folke, C. 2004. Traditional knowledge in social-ecological systems. Ecology and Society 9(3):7. [online] URL: http://ww w.ecologyandsociety.org/vol9/iss3/art7/

Folke, C., T. Hahn, P. Olsson, and J. Norberg. 2005. Adaptive governance of social ecological systems. Annual Review of Environment and Resources 30:441-473. http://dx.doi.org/10 .1146/annurev.energy.30.050504.144511

Gooch, S., and J. Warburton. 2009. Building and managing resilience in community-based NRM Groups: an Australian case study. Society and Natural Resources 22:158-171. http:/ /dx.doi.org/10.1080/08941920801967880

Gratani, M., J. R. A. Butler, F. Royee, P. Valentine, D. Burrows, W. I. Canendo, and A. S. Anderson. 2011. Is validation of indigenous ecological knowledge a disrespectful process? A case study of traditional fishing poisons and invasive fish management from the wet tropics, Australia. Ecology and Society 16(3):25. http://dx.doi.org/10.5751/ES-0 $\underline{4249-160325}$

Head, B. W. 2007. Community engagement: participation on whose terms? Australian Journal of Political Science 42:441-454.

Head, B. W. 2009. From government to governance: explaining and assessing new approaches to NRM. Pages
15-28 in M. B. Lane, C. J. Robinson, and B. M. Taylor, editors. Contested country: local and regional environmental management in Australia. CSIRO Publishing, Canberra, Australia.

Hibbard, M., and M. B. Lane. 2004. By the seat of your pants: indigenous action and state response. Planning Theory \& Practice 5:95-102. http://dx.doi.org/10.1080/1464935042000 $\underline{204213 \mathrm{a}}$

Hill, R. 2011. Towards equity in indigenous co-management of protected areas: cultural planning by Miriuwung-Gajerrong people in the Kimberley, Western Australia. Geographical Research 49:72-85. http://dx.doi.org/10.1111/j.1745-5871.20 10.00669.x

Hill, R. 2006. The effectiveness of agreements and protocols to bridge between indigenous and non-indigenous tool-boxes for protected area management: a case study from the wet tropics of Queensland. Society and Natural Resources 19:577-590. http://dx.doi.org/10.1080/08941920600742310

Hill, R., D. Buchanan, and A. Baird. 1999. Aborigines \& fires in the wet tropics of Queensland, Australia: ecosystem management across cultures. Society and Natural Resources 12:205-223. http://dx.doi.org/10.1080/089419299279704

Hill, R., G. Turpin, W. Canendo, P. Standley, D. Crayn, S. Warne, K. Keith, E. Addicott, and F. Zich. 2011. Indigenousdriven tropical ethnobotany. Australasian Plant Conservation 19:7-8.

Hill, R., F. Walsh, J. Davies, and M. Sandford. 2011. Our country our way: guidelines for Australian Indigenous protected area management plans. Australian Government, CSIRO Ecosystem Sciences and Department of Sustainability, Water, Environment, Population and Communities, Cairns, Australia.

Hill, R., K. J. Williams, P. L. Pert, C. J. Robinson, A. P. Dale, D. A. Westcott, R. A. Grace, and T. O'Malley. 2010. Adaptive community-based biodiversity conservation in Australia's tropical rainforest. Environmental Conservation 37:73-82.

http://dx.doi.org/10.1017/S0376892910000330

Hill, R., and L. J. Williams. 2009. Indigenous natural resource management: overcoming marginalisation produced in Australia's current NRM model. Pages 161-178 in M. B. Lane, C. J. Robinson, and B. M. Taylor, editors. Contested country: local and regional environmental management in Australia. CSIRO Publishing, Canberra, Australia.

Hinkson, M., and B. Smith. 2005. Introduction: conceptual moves towards an intercultural analysis. Oceania 75:157-166.

Houde, N. 2007. The six faces of traditional ecological knowledge: challenges and opportunities for Canadian co- 
management arrangements. Ecology and Society 12(2):17. [online] URL: http://www.ecologyandsociety.org/vol12/iss2/ $\underline{\operatorname{art} 34 /}$

Hunt, J. 2008. Development in indigenous Australia: international meanings and local approaches. Presentation to the Centre for Aboriginal Economic Policy Research Seminar Series, 11 June 2008. Australian National University (ANU), Canberra, Australia. [online] URL: http://http://caepr.anu.edu. au/sites/default/files/Seminars/presentations/Hunt_Development

Hunt, J., D. Smith, S. Garling, and W. Sanders, editors. 2008. Contested governance. Culture, power and institutions in indigenous Australia. Research Monograph No. 29. Australian National University (ANU), Canberra, Australia. http://dx.doi.org/10.1177/096746089900600415

International Council for Science (ICSU). 2002. Science, traditional knowledge and sustainable development. Series on science for sustainable development No. 4. International Council for Science and the United Nations Education, Scientific and Cultural Organisation, Paris, France.

Jackson, S. 2009. Recognition of indigenous interests in Australian water resource management, with particular reference to environmental flow assessment. Geography Compass 2:874-898. http://dx.doi.org/10.1111/j.1749-8198.2 008.00103.X

Jackson, S., and J. C. Altman. 2009. Indigenous rights and water policy: perspectives from tropical Northern Australia. Australian Indigenous Law Review 13:27-48.

La Fontaine, M. 2006. New legend: a story of law and culture and the fight for self-determination in the Kimberley. Kimberley Aboriginal Law and Culture Centre, Fitzroy Crossing, Australia.

Lane, M. B., B. Taylor, and C. J. Robinson, editors. 2009. Contested country: local and regional environmental management in Australia. CSIRO Publishing, Canberra, Australia.

Lane, M. B., and L. Williams. 2009. The Natural Heritage Trust and indigenous lands: the trials and tribulations of 'new technologies of governance' Australian Geographer 40:85-107.

Lebel, L., J. M. Anderies, B. Campbell, C. Folke, S. HatfieldDodds, T. P. Hughes, and J. Wilson. 2006. Governance and the capacity to manage resilience in regional social-ecological systems. Ecology and Society 11(1):19. [online] URL: http:// www.ecologyandsociety.org/vol11/iss1/art19/

Liamputtong, P., and D. Ezzy. 2005. Qualitative research methods. Oxford University Press, Melbourne, Australia.

Lockwood, M. 2010. Good governance for terrestrial protected areas: a framework, principles and performance outcomes. Journal of Environmental Management 91:754-766. http://dx.doi.org/10.1016/j.jenvman.2009.10.005

Lockwood, M., J. Davidson, A. Curtis, E. Stratford, and R. Griffith. 2009. Multi-level environmental governance: lessons from Australian natural resource management. Australian Geographer 40:169-186. http://dx.doi.org/10.1080/00049180 $\underline{902964926}$

Lynam, T., W. de Jong, D. Sheil, T. Kusumanto, and K. Evans. 2007. A review of tools for incorporating community knowledge, preferences, and values into decision making in natural resources management. Ecology and Society 12(1):5. [online] URL: http://www.ecologyandsociety.org/vol12/iss1/ $\underline{\operatorname{art} 5 /}$

Margerum, R. D. 2008. A typology of collaboration efforts in environmental management. Environmental Management 41:487-500. http://dx.doi.org/10.1007/s00267-008-9067-9

Martinez-Cobo, J. 1986. Problem of discrimination against indigenous populations. United Nations Permanent Forum of Indigenous Peoples, New York, USA.

Merlan, F. 2005. Explorations towards intercultural accounts of socio-cultural reproduction and changes. Oceania 75:167-182.

Michener, V. J. 1998. The participatory approach: contradiction and co-option in Burkina Faso. World Development 26:2105-2118. http://dx.doi.org/10.1016/S0305 $\underline{-750 \times(98) 00112-0}$

Muller, S. 2003. Towards decolonisation of Australia's protected area management: the Nantawarrina Indigenous Protected Area Experience. Geographical Research 41:29-43.

Nakanura, N. 2008. An 'effective' involvement of indigenous people in environmental impact assessment: the cultural impact assessment of the Saru River Region, Japan Australian Geographer 39:427-444.

Natcher, D. C., S. Davis, and C. G. Hickey. 2005. Comanagement: managing relationships, not resources. Human Organization 64:240-250.

Natural Resource Management Ministerial Council (NRMMC). 2010. Australia's Biodiversity Conservation Strategy 2010-2030. National Biodiversity Strategy Review Task Group convened under the Natural Resource Management Ministerial Council, Australian Government, Department of Environment, Water, Heritage and the Arts, Canberra, Australia.

Nursey-Bray, M. 2009. A Guugu Yimmithir Bam Wii: Ngawiya and Girrbithi: hunting, planning and management along the Great Barrier Reef, Australia. Geoforum 40:442-453. http://dx.doi.org/10.1016/j.geoforum.2009.02.002 
Nursey-Bray, M., and P. Rist. 2009. Co-management and protected area management: achieving effective management of a contested site, lessons from the Great Barrier Reef World Heritage Area (GBRWHA). Marine Policy 33:118-127. http: //dx.doi.org/10.1016/j.marpol.2008.05.002

O'Connor, M. H., and S. M. Prober. 2010. A calendar of Ngadju seasonal knowledge. CSIRO Sustainable Ecosystems, Floreat, Australia. [online] URL: http://www.csiro.au/files/files/ pzpj.pdf

Olsson, P., C. Folke, and F. Berkes. 2004. Adaptive comanagement for building resilience in social ecological systems. Environmental Management 34:75-90. http://dx.doi. org/10.1007/s00267-003-0101-7

Olsson, P., L. H. Gunderson, S. R. Carpenter, P. Ryan, L. Lebel, C. Folke, and C. S. Holling. 2006. Shooting the rapids: navigating transitions to adaptive governance of SESs. Ecology and Society 11(1):18. [online] URL: http://www.eco logyandsociety.org/vol11/iss1/art18/

Ostrom, E. 2007. A diagnostic approach for going beyond panaceas. Proceedings of the National Academy of Science 104:15181-15187. http://dx.doi.org/10.1073/pnas.0702288104

Ostrom, E. 2008. Institutions and the environment. Economic Affairs 28:24-31. http://dx.doi.org/10.1111/j.1468-0270.2008 $.00840 . \mathrm{x}$

Ostrom, E., and M. Cox. 2010. Moving beyond panaceas: a multi-tiered diagnostic approach for social-ecological analysis. Environmental Conservation 37:451-463. http://dx.d oi.org/10.1017/S0376892910000834

Palmer, L. 2006. 'Nature', place and the recognition of indigenous politics. Australian Geographer 37:33-43. http://d x.doi.org/10.1080/00049180500511954

Pickerill, J. 2008. From wilderness to WildCountry: the power of language in environmental campaigns in Australia. Environmental Politics 17:95-104. http://dx.doi.org/10.1080/ 09644010701811681

Plummer, R., and J. FitzGibbon. 2004. Some observations on the terminology in co-operative environmental management. Journal of Environmental Management 70:63-72. http://dx.do i.org/10.1016/j.jenvman.2003.10.005

Porter, L. 2004. Unlearning one's privilege: reflections on cross-cultural research with indigenous peoples in South-East Australia. Planning Theory and Practice 5:104-109. http://dx. doi.org/10.1080/1464935042000204222

Prober, S. M., M. H. O'Connor, and F. J. Walsh. 2011. Australian aboriginal peoples' seasonal knowledge: a potential basis for shared understanding in environmental management.
Ecology and Society 16(2):12. [online] URL: http://www.eco logyandsociety.org./vol16/iss2/art12/

Reconciliation Australia. 2002. Indigenous Governance Conference outcomes Reconciliation Australia, the Aboriginal and Torres Strait Islander Commission, and the National Institute for Governance, Canberra, Australia. [online] URL: http://www.reconciliation.org.au/igawards/pages/about-governance/ conference.php

Reed, M. S. 2008. Stakeholder participation for environmental management: a literature review. Biological Conservation 141:2417-2431. http://dx.doi.org/10.1016/j.biocon.2008.07.014

Robins, S. 2003. Whose modernity? Indigenous modernities and land claims after apartheid. Development and Change 34:265-286. http://dx.doi.org/10.1111/1467-7660.00305

Robinson, C. J., and N. Munungguritj. 2001. Sustainable balance: a Yolngu framework for cross-cultural collaborative management. Pages 92-107 in R. Baker, J. Davies, and E. Young, editors. Working on country: indigenous environmental management in Australia. Oxford University Press, Melbourne, Australia.

Robinson, G. M. 1998. Methods and techniques in human geography. John Wiley \& Sons, Chichester, UK.

Roder, C. 2008. Cultural heritage mapping project. Rainforest Aboriginal News 11:5-6.

Rose, D. B. 1994. Whose confidentiality? Whose intellectual property? Pages 1-11 in Claims to knowledge, claims to country. Native title, native title claims and the role of the anthropologist. Proceedings of a conference session on native title at the annual conference of the Australian Anthropological Society. Institute of Aboriginal and Torres Strait Islander Studies, Canberra, Australia.

Ross, A., and K. Pickering. 2002. The politics of reintegrating Australian aboriginal and American Indian indigenous knowledge into resource management: the dynamics of resource appropriation and cultural revival. Human Ecology 30:187-214. http://dx.doi.org/10.1023/A:1015640713250

Ross, H., C. Grant, C. J. Robinson, A. Izurieta, D. Smyth, and P. Rist. 2009. Co-management and indigenous protected areas in Australia: achievements and ways forward. Australasian Journal of Environmental Management 16:51-61.

Roughley, A., and S. Williams. 2007. The engagement of indigenous Australians in natural resource management: key findings and outcomes from Land \& Water Australia funded research and the broader literature. Land \& Water Australia, Canberra, Australia.

Sandström, C. 2009. Institutional dimensions of comanagement: participation, power and process. Society and Natural 
Resources 22:230-244. http://dx.doi.org/10.1080/0894192080 2183354

Selin, H., and S. T. VanDeveer, editors. 2009. Changing climates in North American politics: institutions, policymaking and multilevel governance. The MIT Press, Cambridge, Massachusetts, USA.

Sen, A. 2005. Human rights and capabilities. Journal of Human Development 6:151-166. http://dx.doi.org/10.1080/14 $\underline{649880500120491}$

Servaes, J., and L. Obijiofor. 2007. Special issue: indigenous cultures and diffusion of innovations. International Journal of Agricultural Resources, Governance and Ecology 6:593-705.

Sillitoe, P., and M. Marzano. 2009. Future of indigenous knowledge research in development. Futures 41:13-23. http:/ /dx.doi.org/10.1016/j.futures.2008.07.004

Smith, D., and J. Hunt. 2008. Understanding indigenous Australian governance - research, theory and representations. Pages 1-23 in J. Hunt, D. Smith, S. Garling, and W. Sanders, editors. Contested governance. Culture, power and institutions in indigenous Australia Research Monograph No. 29. Australian National University, Canberra, Australia.

Smith, L. T. 1999. Decolonizing methodologies: research and indigenous Peoples. Zed Books Ltd and University of Otago Press, London, UK, and Dunedin, New Zealand.

Standley, P., N. J. Bidwell, T. George, V. Steffensen, and J. Gothe. 2009. Connecting communities and the environment through media: doing, saying and seeing along traditional knowledge revival pathways. Journal of Community, Citizen's and Third Sector Media and Communication 5:9-27.

Stork, N. E., S. Goosem, and S. M. Turton. 2008. Australian rainforests in a global context. Pages 4-20 in N. E. Stork, and S. M. Turton, editors. Living in a dynamic tropical forest landscape. Blackwell Publishing, Oxford, UK. http://dx.doi.o rg/10.1002/9781444300321.ch1

Suchet-Pearson, S., and R. Howitt. 2006. On teaching and learning resource and environmental management: reframing capacity building in multicultural settings. Australian Geographer 37:117-128. http://dx.doi.org/10.1080/00049180 $\underline{500512010}$

Sveiby, K. E. 2009. Aboriginal principles for sustainable development as told in traditional law stories. Sustainable Development 17:341-356. http://dx.doi.org/10.1002/sd.389

Talbot, L. D. 2005. Indigenous land management techniques of the Djabugay people. Thesis. School of Tropical Environment Studies and Geography, James Cook University, Cairns, Australia.

Telfer, W. R., and M. J. Garde. 2006. Indigenous knowledge of rock kangaroo ecology in western Arnhem Land, Australia.
Human Ecology 34:379-406. http://dx.doi.org/10.1007/s1074 $\underline{\text { 5-006-9023-3 }}$

Tobias, T. N. 2010. Living proof. The essential data collection guide for indigenous use and occupancy map survey Ecotrust Canada and the Union of British Columbia Indian Chiefs, Vancouver, Canada.

Walker, B. H., and D. Salt. 2006. Resilience thinking: sustaining ecosystems and people in a changing world. Island Press, Washington, D.C., USA.

Walker, B. H., L. H. Gunderson, A. P. Kinzig, C. Folke, S. R. Carpenter, and L. Schultz. 2006. A handful of heuristics and some propositions for understanding resilience in socialecological systems. Ecology and Society 11(1):13. [online] URL: http://www.ecologyandsociety.org/vol11/iss1/art13/

Walker, D., J. P. Jones, S. M. Roberts, and O. R. Frohling. 2007. When participation meets empowerment: The WWF and the politics of invitation in the Chimalapas, Mexico. Annals of the Association of American Geographers 97:423-444. http://dx.doi.org/10.1111/j.1467-8306.2007.00546. $\underline{\mathrm{X}}$

Weir, J. K. 2009. Murray River Country: an ecological dialogue with traditional owners. Aboriginal Studies Press, Canberra, Australia.

Wet Tropics Management Authority, Queensland Environmental Protection Agency, Queensland Parks and Wildlife Service, Queensland Department of Natural Resources and Mines and The Commonwealth of Australia - the Department of Environment and Heritage, and Rainforest Aboriginal People. 2005. Wet tropics of Queensland World Heritage Area Regional Agreement between Rainforest Aboriginal People and the Wet Tropics Management Authority, Queensland Environmental Protection Agency, Queensland Parks and Wildlife Service, Queensland Department of Natural Resources and Mines and The Commonwealth of Australia the Department of Environment and Heritage - For Management of Wet Tropics World Heritage Area. Wet Tropics Management Authority, Cairns, Australia.

Wilmsen, C., W. Elmendorf, L. Fisher, J. Ross, B. Sarathy, and G. Wells, editors. 2008. Partnerships for empowerment: participatory research for community-based natural resource management. Earthscan, London, UK.

Winter, G. 2006. Introduction. Pages 1-34 in G. Winter, editor. Multilevel governance of global environmental change: perspectives from science, sociology and the law. Cambridge University Press, Cambridge, UK.

Wohling, M. 2009. The problem of scale in indigenous knowledge: a perspective from Northern Australia. Ecology and Society 14(1):1. [online] URL: http://www.ecologyandso ciety.org/vol14/iss1/art1/ 